ks. Lucjan Świto

\title{
Od amencji do borderline. Dopuszczenie do małżeństwa osób z zaburzeniem natury psychicznej?
}

\section{Prawo do małżeństwa}

Prawo do zawarcia małżeństwa (ius connubii) jest jednym z najbardziej podstawowych i niezbywalnych praw człowieka, wynikającym z godności osoby ludzkiej. Od zarania bowiem dziejów człowiek spotyka się z tajemnicą stworzenia, w którą wpisane jest powołanie mężczyzny i kobiety do tworzenia wspólnoty - rodziny ludzkiej. Zawarte w akcie stworzenia powołanie małżeńskie, rodzące się z powołania człowieka do miłości, która jest podstawowym i wrodzonym powołaniem każdej istoty ludzkiej, stanowi dla mężczyzny i kobiety nie tylko wzajemne uzupełnienie się fizyczne, lecz także możliwość obopólnego ubogacania się w sferze duchowej i nadprzyrodzonej ${ }^{1}$.

1 Por. W. Góralski, Studia nad małżeństwem i rodzina, Warszawa 2007, s. 173194; W. Góralski, „Ius connubii” w kodeksach prawa kanonicznego z 1917 oraz z 1983 roku, w: Historia magistra vitae. Księga jubileuszowa ku czci Profesora Jerzego Flagi, red. A. Dębiński, S. Wrzosek, K. Maćkowska, M. Kruszewska-Gadoś, Lublin 2007, s. 187; L. Świto, Zasada „favor matrimonii” w Kodeksie Prawa Kanonicz- 
Z uwagi na doniosłość instytucji małżeństwa, które zapoczątkowuje rodzinę, małżeństwo jest przedmiotem zainteresowania i troski wielu podmiotów, wśród nich wspólnoty Kościoła. Zawarcia małżeństwa nie można bowiem sprowadzić tylko do czysto osobistych i prywatnych relacji między małżonkami, gdyż małżeństwo zapoczątkowujące rodzinę stanowi fundament społeczeństwa, podniesione zaś do godności sakramentalnej oznacza nierozerwalną wspólnotę, różniącą się od innych ludzkich związków. Zatem troska Kościoła o małżeństwo i rodzinę wyraża się przede wszystkim w kształtowaniu odpowiedniego ustawodawstwa, które byłoby rękojmią dla realizacji naturalnego prawa do małżeństwa².

Kanoniczny porządek prawny zabezpiecza to naturalne prawo do małżeństwa, redukując do minimum ingerencję prawodawcy kościelnego ograniczającą wolność nupturientów. Zasadę tę wyraża przede wszystkim norma kan. 219 KPK³, która stanowi, iż wszyscy wierni mają prawo być wolni od jakiegokolwiek przymusu w wyborze stanu życia, oraz norma kan. 1058 KPK, mówiąca, że małżeństwo mogą zawrzeć wszyscy, którym prawo tego nie zabrania. Ograniczenia wykonywania prawa do zawarcia małżeństwa wprowadzone przez prawodawcę kościelnego mają zawsze charakter czegoś wyjątkowego i wymagają wyraźnej dyspozycji legislacyjnej ${ }^{4}$, dotyczą bowiem okoliczności, które ustawodawca kościelny uznaje za nie do pogodzenia z przyjęciem stanu życia

nego z 1983 r., w: Favor matrimonii? Teoria i praktyka, red. L. Świto, M. Tomkiewicz, Olsztyn 2014, s. 59-6o.

2 Por. L. Świto, Trwatość i nierozerwalność matżeństwa w ujęciu prawa polskiego i kanonicznego, „Forum Teologiczne” 13 (2012), s. 69-83.

3 Codex Iuris Canonici auctoritate Joannis Pauli PP. II promulgatus, Typis Polyglottis Vaticanis 1983. Kodeks prawa kanonicznego. Przekład polski zatwierdzony przez Konferencję Episkopatu, Poznań 1984.

4 Kan. 1075 KPK: „§ 1. Jedynie najwyższa władza kościelna może autentycznie wyjaśniać, kiedy prawo Boże zabrania małżeństwa lub ją unieważnia. § 2. Rów- 
małżeńskiego, biorąc pod uwagę racje natury osobowej, kościelnej i społecznej, a w sposób szczególny ochronę istotnych wartości samej instytucji małżeńskiej oraz troskę o zbawienie dusz (salus animarum)5. Okolicznością, która niewątpliwie znacząco może wpłynąć na stan życia małżeńskiego, jest sposób funkcjonowania władz psychosomatycznych, intelektualnych i wolitywnych nupturientów, czyli stan ich zdrowia psychicznego. W związku z tym rodzi się pytanie o możliwość dopuszczenia do małżeństwa osób z zaburzeniami psychicznymi, czyli czy prawo do zawarcia małżeństwa (ius connubi) ma jakieś granice normatywne w tym względzie, a jeśli tak, to co te granice wyznacza? W poszukiwaniu odpowiedzi zostanie poddana analizie doktryna kanonistyczna ostatniego stulecia, ukształtowana kodyfikacjami prawa kanonicznego z $1917^{6}$ i 1983 roku.

\section{Ograniczenia ius connubi w Kodeksie prawa kanonicznego z 1917 roku}

Udzielając odpowiedzi na postawione wyżej pytanie, należy stwierdzić od razu, że zarówno pod rządami starego, jak i nowego Kodeksu prawa kanonicznego, prawo do zawarcia małżeństwa miało i ma nadal swoje granice. Wiążą się one - ujmując rzecz w dużym skrócie - z kondycją psychiczną człowieka, czyli z jego zdolnością lub brakiem tej zdolności do wyrażenia zgody małżeńskiej, która - jak wiemy - konstytuuje małżeństwo. To jednak, co się zmieniło na przestrzeni ostatniego stulecia, to rozumienie tych granic. Nie ulega bowiem wątpliwości, że owe granice, czyli

nież tylko najwyższa władza kościelna ma prawo ustanawiać inne przeszkody dla ochrzczonych".

5 P. Moneta, Il diritto al matrimonio (can. 1058), w: Diritto matrimoniale canonico, a cura di P. Bonnet, C. Gullo, t. 1, Città del Vaticano 2002, s. 192.

6 Codex Iuris Canonici Pii x Pontificis Maximi iussu digestus, Benedicti Papae Xv auctoritate promulgatus, Romae 1918. 
kanoniczne ograniczenia w realizacji ius connubi, są bardzo silnie związane z ewolucją nauk medycznych z dziedziny psychiatrii, psychologii czy psychopatologii. Podczas jednak gdy pod wczesnymi rządami kodeksu Pio-Benedyktyńskiego przy ocenie zdolności do wyrażenia zgody małżeńskiej odwoływano się przede wszystkim do pojęć inspirowanych symptomatologią choroby umysłowej, jak amencja, demencja, lucida intervalla, furiosi, stupidi, fatui 7 , tak dziś stosowana przez dawną doktrynę i orzecznictwo terminologia chorób i zaburzeń umysłowych, wraz z rozwojem psychopatologii i psychiatrii, uległa dezaktualizacji. Pojawiły się bowiem i wciąż pojawiają coraz to nowe terminy chorób i jednostek zaburzeń osobowości, których usytuowanie nie tylko wewnątrz tradycyjnych klasyfikacji kanonicznych, ale w ogóle usystematyzowanie ich w naukach medycznych stało się polemiczne. Są to różnego rodzaju choroby utajone, choroby o przebiegu rozwojowym, zaburzenia psychologiczne afektywności lub orientacji i skłonności seksualnych czy syndrom borderline.

Nie sposób - z uwagi na ramy wynikające z formy tej publikacji - poświęcić więcej uwagi wszystkim chorobom i zaburzeniom osobowości, które uwarunkowują zdolność do wyrażenia zgody małżeńskiej, dlatego w kilku słowach przedstawimy te, wskazane w tytule prezentacji, gdyż po pierwsze zdają się one pozostawać na przeciwległych biegunach skali dysfunkcji psychicznych, a po wtóre są one - w pewnej mierze - reprezentatywne dla zobrazowania ewolucji, o której wspomnieliśmy. Czym więc jest amentia i czym borderline?

7 Por. S. Biskupski, Prawo małżeńskie Kościoła rzymskokatolickiego, Warszawa 1956, s. 274-277. 


\section{Amencja}

Odpowiadając na pytanie, czym jest „amencja”, trzeba na wstępie zaznaczyć, że wymienione wyżej terminy (dziś już archaiczne) inspirowane symptomatologią choroby umysłowej, którymi posługiwała się doktryna i orzecznictwo przed 1983 rokiem, nawiązywały wprost do defektów i zaburzeń władz umysłowych, które klasyfikowano, inspirując się dawną normą kan. 2201 Kodeksu prawa kanonicznego z 1917 roku, według - jak zauważa trafnie Pedro-Juan Viladrich - następującego podziału:

1) Trwałe i całkowite anomalie i zaburzenia zdrowia umysłowego nazywano amentia habitualis. W tej kategorii chorób umysłowych rozróżniano między amencją zupełną, która czyniła podmiot niezdolnym do używania rozumu w jakimkolwiek aspekcie życia, a więc również do małżeństwa, i amencją częściową, która oddziaływała na podmiot tylko w pewnych sferach życia.

2) Wyszczególniano zaburzenia umysłowe o charakterze przejściowym (mentis exturbatio), które w odróżnieniu od amencji zupełnej kompletnie pozbawiały normalnego używania władz umysłowych, ale tylko przez okres przejściowy lub chwilowy i uniezdalniały lub nie w zależności od tego, czy akt zawarcia małżeństwa dokonywał się czy nie, pod wpływem tego przejściowego zaburzenia.

3) Wyróżniano tzw. upośledzenie umysłowe (mentis debilitas), kategorię przypisywaną podmiotowi z niedoskonałym używaniem rozumu, które mogło być wrodzone lub nabyte i stałe lub przejściowe. Aby ta wada umysłowa pociągała za sobą niezdolność, powinna być wystarczająco poważna, tak aby uniemożliwić w sposób

8 W języku polskim termin „amencja” (łac. amentia) stosowano zamiennie z terminem „splątanie” lub „zespół splątaniowy” bądź „zespół amentywny”. Oznaczał on zaburzenie świadomości będące przejawem ciężkiej dysfunkcji mózgu. Zob. M. Jarema, J. Rabe-Jabłońska, Psychiatria: podręcznik dla studentów medycyny. Warszawa 2011, s. 28-29. 
stały rozeznanie oceniające, które jako aktualne i proporcjonalne jest wymagane w zgodzie małżeńskiej.

\section{Borderline}

Przechodząc z kolei do współczesnego nam terminu borderline ${ }^{10}$, termin ten można byłoby scharakteryzować - jak to trafnie ujęto - w trzech pojęciach: pomieszanie, chaos, poczucie niejasności. Tymi słowami można bowiem próbować opisać nie tylko to, co przeżywają i jak funkcjonują osoby z tym rozpoznaniem, ale także i to, co pojawia się przy próbach zdefiniowania i wyjaśnienia, czym jest i jak kształtuje się „osobowość z pogranicza” lub inaczej „osobowość borderline”.

Wielu bowiem specjalistów z zakresu psychologii czy psychiatrii nie jest w stanie w ogóle rozpoznać objawów borderline, ponieważ - jak twierdzą - nie mają wystarczającej wiedzy na temat tego zaburzenia. Inni odrzucają tego typu diagnozę, uważając ją za zbyt pojemną lub traktując ją jako etykietę dla trudnych pacjentów, powstałą z braku łatwo dostępnych alternatyw. Wreszcie jeszcze inni uważają, że diagnozowanie borderline stygmatyzuje ${ }^{12}$.

9 Por. P. Viladrich, Konsens matżeński. Sposoby prawnej oceny i interpretacji w kanonicznych procesach o stwierdzenie nieważności matżeństwa, Warszawa 2002, s. 101-102. Zob. też S. Biskupski, Prawo małżeńskie Kościoła rzymskokatolickiego, Warszawa 1956, s. 275.

10 „Osobowość chwiejna emocjonalnie typu borderline” (ang. borderline personality disorder, BPD). W kryteriach diagnostycznych ICD-10 „osobowość chwiejna emocjonalnie" (F6o.3), która występuje w dwóch podtypach: impulsywnym (F6o.30) i borderline (F6o.31). Szerzej zob. M. J. Horowitz, Psychotherapy for Borderline Personality: Focusing on Object Relations, "The American Journal of Psychiatry" 163 (2006) no. 5, s. 944.

11 T. Millon, R. Davis, Zaburzenia osobowości we współczesnym świecie, Warszawa 2005, s. 603-605.

12 Por. P. Mason, Borderline. Jak żyć z osobq o skrajnych emocjach, Sopot 2013, s. 33 . 
Problem z klasyfikacją zaburzeń z pogranicza nie jest tylko semantyczny. Dawniej stosowano tę diagnozę wobec zróżnicowanej grupy słabo zdefiniowanych zaburzeń, które nie odpowiadały tradycyjnym kryteriom diagnostycznym i były cięższe niż nerwice, a mniej ostre niż schizofrenia. Dopiero niedawno diagnoza zaburzeń z pogranicza zyskała status odrębnej kategorii, ale nadal nie ma zgodności co do ich specyficznej natury ${ }^{13}$.

Termin „osobowość z pogranicza” został stworzony w połowie $\mathrm{xx}$ wieku, aby objąć tych pacjentów, którzy pod względem objawów i funkcjonowania nie mieścili się jednoznacznie ani w kategorii psychoz, ani nerwic. Zaczęto się bowiem zastanawiać, czy zagadkowa patologia jest rodzajem poważnych zaburzeń charakteru czy mniej ostrą postacią schizofrenii. Pacjenci ci rzadko mieli urojenia czy halucynacje lub nie doświadczali ich wcale. Nie można ich było określić jako psychotycznych. Brakowało im jednocześnie stabilności i przewidywalności charakteryzujących pacjentów neurotycznych, a ich cierpienie wydawało się głębsze i mniej zrozumiałe niż osób neurotycznych. Często mówi się o takich osobach, że są stabilne w swej niestabilności. Można powiedzieć, że osoby te mają kontakt z rzeczywistością i są zdolne do tego, aby przez większość czasu dobrze funkcjonować i odnajdywać się w ogólnej rzeczywistości. Jednak problem ujawnia się w tym, jakie sposoby i mechanizmy stosują, aby utrzymać kontakt nie tylko ze światem zewnętrznym, ale także z samymi sobą ${ }^{14}$.

Osobowość z pogranicza ma słabe poczucie integracji siebie, często czuje się „rozmyta”, „płynna”. Nie wie, nie czuje, jaka jest na stałe. Takie poczucie braku siebie utrudnia stawianie czoła trudnościom, radzenie sobie ze stresem i napięciem, ale także

13 Por. E. Goldstein, Zaburzenia z pogranicza. Modele kliniczne i techniki terapeutyczne, Gdańsk 2003, s. 25.

14 Por. N. McWilliams, Diagnoza psychoanalityczna, Gdańsk 2009, s. 72-75. 
zaburza budowanie kontaktu z ludźmi i realizację własnych potrzeb. Ich świat wewnętrzny i relacji z innymi zdominowany jest wówczas przez chwiejność, niestabilność i złość.

Osoby takie są bardzo zmiennie emocjonalnie. W krótkim czasie ich nastrój przechodzi od radości, wręcz euforii, przez drażliwość, lęk do poczucia beznadziei i depresji. Mają dużą podatność na zranienie. Niezwykle szybko i często przechodzą od idealizacji do dewaluacji również innych. Potrafią w krótkim czasie przejść od deklarowania „miłości aż po grób” do zupełnego przeciwieństwa, jakim jest nienawiść. Tym, co najbardziej je przeraża, jest opuszczenie, porzucenie. Stale przeżywają wiele trudnych stanów emocjonalnych: lęk, poczucie winy, przygnębienie, poczucie beznadziei i bezradności. Nie wiedzą, kim są i jakie mają potrzeby, wartości. Nie mają także jasności, kim są i czego potrzebują inni ludzie. Granica pomiędzy „ja” a „inni” zaciera się, wywołując przerażenie, gniew i bezradność.

Niemożność poradzenia sobie „wewnątrz siebie” z takim nawałem emocji powoduje, że osobowości z pogranicza muszą pozbyć się tego na „zewnątrz siebie” - między innymi okaleczeją się, uciekają w alkohol, narkotyki, hazard lub przypadkowy seks, czy dokonują prób samobójczych. Takie emocjonalne przeciążenie może być też przyczyną krótkotrwałych i przemijających stanów psychotycznych lub dysocjacji ${ }^{15}$.

15 Por. też J. Aleksandrowicz, Psychopatologia zaburzeń nerwicowych i osobowości, Kraków 2002, passim; Psychoterapia psychodynamiczna zaburzeń osobowości. Podręcznik kliniczny, red. J. Clarkin, P. Fonagy, G. Gabbard, Kraków 2013, passim; R. Meyer, Psychopatologia, Gdańsk 2003, passim; O. Kernberg, M. Selzer, H. Koenigsberg, A. Carr, A. Appelbaum, Psychodynamiczna terapia pacjentów borderline, Gdańsk 2007, passim; R. Vaughan, Poradnictwo pastoralne a zaburzenia osobowości, Kraków 1999, passim; Psychiatria. Podręcznik dla studentów medycyny, red. A. Bilikiewicz, Warszawa 2004, passim. 
Jak zatem z powyższego wynika, kryteria diagnostyczne zaburzenia osobowości borderline są bardzo rozległe i zdecydowanie różnią się od tych, którymi posługiwała się kanonistyka na progu xx wieku przy określaniu granic zdolności do wyrażenia zgody małżeńskiej. Nie sposób przy tym nie zauważyć, że nie wszystkie z pojęć wyżej wymienionych dają się zdefiniować lub choćby zobrazować w sposób jasny i klarowny. W psychologii czy psychiatrii nie ma wyraźnych granic pomiędzy odczuciami, które są prawidłowe, a odczuciami patologicznymi. Zachowanie, które jest inne niż oczekiwane przez społeczeństwo, nie musi zostać wszak uznane za przejaw zaburzenia psychicznego ${ }^{16}$.

\section{Niezdolność konsensualna}

Gwałtowny rozwój nauk psychologiczno-psychiatrycznych opisujących kondycję psychiczną nupturientów bardzo mocno odsłonił nieadekwatność dotychczasowych kanonicznych narzędzi określających niezdolność do małżeństwa, wskazanych w kan. 2201 KPK z 1917 roku i ujawnił potrzebę nowego, systemowego ujęcia analizowanego zagadnienia.

Przełomowym momentem dla określenia granic prawa do zawarcia małżeństwa, czyli zdolności człowieka do wyrażenia zgody małżeńskiej, stała się rozpoczęta w latach sześćdziesiątych $\mathrm{xx}$ wieku redakcja dzisiejszej normy kan. 1095 KPK, która weszła w życie w 1983 roku. Określiła ona źródła tzw. zdolności konsensualnej, a także trzy kryteria jej miary obecności lub nieobecności u nupturientów. Zostały one ujętew następujących punktach:1) „brak wystarczającego używania rozumu”; 2) „poważny brak rozeznania oceniającego”; 3) „niezdolność do podjęcia istotnych obowiązków małżeńskich”"

16 Por. Z. Falicki, Psychiatria społeczna, Warszawa 1985, s. 114.

17 Zob. szerzej: W. Góralski, G. Dzierżoń, Niezdolność konsensualna do zawarcia małżeństwa kanonicznego, Warszawa 2001, s. 59-254. 
Wprowadzona norma zniosła tym samym praktyczną obowiązywalność wcześniejszych klasyfikacji, zbyt powiązanych z pojęciami branymi wprost z dziedziny chorób umysłowych i ze stanem wiedzy z zakresu psychopatologii i psychiatrii, które podlegając ciągłej ewolucji nie zawsze bywały jasne, i wprowadziła kryterium wyłącznie prawne: została ustanowiona podstawa prawna specyficznej „zdolności konsensualnej” i normatywne kryteria miary jej braku.

Mając więc na uwadze kluczowy charakter powyższego rozróżnienia pomiędzy zaburzeniami psychicznymi a zdolnością konsensualną, należy stwierdzić, że istnienia rozmaitych anomalii, zaburzeń, dysfunkcji psychologicznych, nieprawidłowości psychicznych i chorób umysłowych, które opisują i rozpoznają biegli, nie można automatycznie utożsamiać z „niezdolnością konsensualną". Wspomniane bowiem uwarunkowania i sytuacje psychiczne dostarczają jedynie materiału faktycznego, lecz nigdy same w sobie i przez siebie nie stanowią kwalifikacji prawnej, to znaczy nie przesądzają o niezdolności konsensualnej ${ }^{18}$.

Owszem, chociaż istnienie niezdolności konsensualnej opiera się zawsze na fakcie anomalii psychicznej podmiotu, który jest niezdolny, to jednak istnienie anomalii psychicznych niekoniecznie niesie ze sobą niezdolność konsensualną. Innymi słowy: anomalia psychiczna albo choroba umysłowa nigdy nie jest sama w sobie i przez siebie przyczyną nieważności, lecz okolicznością faktyczną podmiotu, na bazie której określa się (oceniając zawsze każdy przypadek z osobna), czy w czasie zawierania małżeństwa był on pozbawiony „wystarczającego używania rozumu”, „koniecznego rozeznania oceniającego”, czy też „możności podjęcia istotnych obowiązków małżeńskich”, które to elementy są normatywnymi kryteriami prawnymi do oceny i określenia „niezdolności

18 Por. P. Viladrich, Konsens matżeński..., dz. cyt., s. 100-103. 
konsensualnej”, o której w kan. 1095 К РК. Nadmienić tu trzeba, że jedna przyczyna psychiczna (np. głęboka, wrodzona oligofrenia) może z prawnego punktu widzenia powodować jednocześnie trzy - wskazane w kan. 1095 KPK - przyczyny nieważności małżeństwa ${ }^{19}$.

Osoba dotknięta jakąś dysfunkcją psychiczną może zatem ważnie zawrzeć małżeństwo, jeżeli w danym przypadku, w momencie wyrażania zgody, ta sytuacja psychiczna nie pozbawia jej „wystarczającego używania rozumu”, „rozeznania oceniającego” i nie „uniemożliwia jej przyjęcia obowiązków małżeńskich”. Nie istnieje tożsamość między anomalią psychiczną lub chorobą umysłową z jednej strony a niezdolnością konsensualną z drugiej. Uwarunkowania faktyczne nie są tym samym, co normy prawne. Dlatego mogą być osoby z zaburzeniami i anomaliami psychicznymi, które posiadają pełną zdolność konsensualną i mogą zawrzeć ważne małżeństwo, czego ograniczać im nie wolno.

\section{Niezdolność konsensualna a przeszkody małżeńskie}

W podsumowaniu powyższych uwag nie sposób zatem nie zadać pytania, które wynika z dotychczasowych rozważań i niejako nasuwa się samo przez się, gdyż jest fundamentalne dla praktyki kanonicznej: kiedy zatem zabraniać, a kiedy dopuszczać do zawarcia małżeństwa w przypadku występowania u nupturienta choroby lub zaburzeń psychicznych?

Na tak postawione pytanie nie ma - jak wydaje się - jednej, uniwersalnej odpowiedzi. Podejmując jednak próbę sformułowania pewnych wskazówek, przede wszystkim należałoby wyjść od zaakcentowania różnic pomiędzy niezdolnością konsensualną

19 Por. P. Viladrich, Konsens matżeński..., dz. cyt., s. 62. 
a przeszkodami małżeńskimi ${ }^{20}$. Pomimo bowiem tego, iż każdy człowiek przez sam fakt bycia człowiekiem posiada fundamentalną zdolność konsensualną wypływającą z wrodzonego posiadania ius connubii, to jednak na skutek szeregu defektów czy nieodpowiednich okoliczności może nie spełniać warunków ważnego korzystania z tego prawa, to znaczy może nie posiadać zdolności do działania.

Na czym więc polega różnica pomiędzy niezdolnością konsensualną a przeszkodami małżeńskimi?

Przy przeszkodach małżeńskich - jak trafnie pisze wspomniany już Viladrich - nupturient jest traktowany jako ten, który z powodu nałożonego na siebie zobiektywizowanego a priori zakazu nie może ważnie - dopóki trwa zakaz - w ogóle wyrazić zgody małżeńskiej. Natomiast w niezdolności konsensualnej nupturient traktowany jest jako ten, który wprawdzie wyraża zgodę, jednak z powodu braku wystarczającego stopnia rozumnej dobrowolności jego zgoda nie może być uznana za ważną. Ta szczególna subiektywna dobrowolność nie jest jednak przeszkodą i nie może nią być, ponieważ musi być mierzona bardziej konkretnie, w każdym przypadku z osobna. Z tego powodu nie może być zobiektywizowana a priori na sposób ogólnego zakazu. Na tę ogólną obiektywizację nie pozwala bowiem odrębność każdego wewnętrznego aktu zgody składanej „tu i teraz”, a także konkretnego podmiotu, który zawsze brany jest pod uwagę z osobna.

Praktyczną konsekwencją rozróżnienia przeszkód małżeńskich od niezdolności konsensualnej jest więc to, że istotny sens, cechy i wymogi charakteryzujące jakąś przeszkodę nie mogą być bezkrytycznie uznawane za cechy i wymogi wykładni niezdolności konsensualnej. Tego niewłaściwego przenoszenia charakterystyk

20 Szerzej o przeszkodach małżeńskich zob. m.in. J. Gręźlikowski, Przeszkody matżeńskie wynikające z węzła religijnego, „Prawo Kanoniczne” 55 (2012) nr 3, s. $73-93$. 
i reguł między przeszkodami a niezdolnością konsensualną trzeba unikać pod groźbą poważnego pomylenia i naruszenia ius connubii.

\section{Zakończenie}

Kończąc, należy powiedzieć, że dopuszczenie osób do małżeństwa z zaburzeniami natury psychicznej wydaje się być dziś, sto lat po promulgacji kodeksu Pio-Benedyktyńskiego, bardziej problematyczne niż dawniej. Z jednej strony nie można bowiem obiektywizować a priori na sposób ogólnego zakazu różnych chorób i zaburzeń psychicznych, jak przy przeszkodach małżeńskich, i zabraniać nupturientom dotkniętym tymi przypadłościami wstępowania w związek małżeński. Z drugiej strony nie można wykluczyć, że pewne dysfunkcje natury psychicznej, jak np. głęboki niedorozwój umysłowy czy poważny organiczny uraz mózgu (zauważalne primo facie) mogą w sposób niejako uprzedzający wskazywać, iż dana osoba nie posiada pełnego i harmonicznego zarządzania swoimi władzami zmysłowymi, pożądawczymi, umysłowymi i wolitywnymi, które są konieczne, by akt zawarcia przez nią małżeństwa był aktem ludzkim. Każdy przypadek należy badać indywidualnie w oparciu o kryteria zawarte w normie kan. 1095 K PK. To znaczy - na ile występujące zaburzenie psychiczne pozbawia nupturienta wystarczającego używania rozumu lub wpływa na jego poważny brak oceniającego rozeznania istotnych praw i obowiązków małżeńskich, czy wreszcie powoduje jego niezdolność do podjęcia istotnych obowiązków małżeńskich. W tym kontekście warto również zwrócić uwagę na potrzebę wyraźnego rozróżnienia pomiędzy niezdolnością czy niemożliwością a trudnościami, niejednokrotnie nawet poważnymi, które mogą występować w konkretnej sytuacji danego człowieka ${ }^{21}$. Preferowanie

21 Por. H. Franceschi, Riconoscimento e tutela dello „ius connubii” nel sistema matrimoniale canonico, Milano 2004, s. 404. 
wizji małżeństwa idealnego może prowadzić do niepomiernie wymagającego i perfekcjonistycznego postrzegania zdolności do małżeństwa, przed czym przestrzegał papież Jan Paweł II w przemówieniach do Trybunału Roty Rzymskiej w latach 1987, 1988 i $1997^{22}$. W wymienionych przemówieniach ojciec święty apelował o kierowanie się w trakcie dokonywania między innymi ocen związanych z konsensem małżeńskim realistyczną wizją osoby ludzkiej jako rzeczywistością będącą w ciągłym rozwoju, wezwaną do dokonywania wyborów odpowiedzialnych z możliwościami początkowymi swojej potencjalności, wzbogacanych coraz bardziej własnym zaangażowaniem ze wsparciem łaski³

Wydaje się, że należy przyjąć stanowisko, iż wspomniane badanie należy pozostawić - zgodnie z dyspozycją kan. 1066-1070 $\mathrm{KPK}^{24}$ - osądowi proboszcza, przy czym osąd ten nie powinien

22 Ioannes Paulus II, Allocutio ad Romanae Rota Auditores, 5.02.1987, „Acta Apostolicae Sedis" [dalej: AAs] 1987, 79, s. 1457; Ioannes Paulus II, Allocutio ad Romanae Rota Auditores, 25.01.1988, AAS 8o (1988), s. 1180-1183; Ioannes Paulus II, Allocutio ad Romanae Rota Auditores, 27.01.1997, AAS 79 (1987), s. 486-489. Tekst polski wraz z komentarzem zob. T. Rozkrut, Jan Pawet II do Roty Rzymskiej, Tarnów 2003.

23 Zob. T. Rozkrut, Jan Pawet II do Roty Rzymskiej, Tarnów 2003.

24 Kan. 1066 KPK: „Przed zawarciem małżeństwa należy się upewnić, że nic nie stoi na przeszkodzie do jego ważnego i godziwego zawarcia”. Kan. 1067 КРК: „Konferencja Episkopatu powinna wydać normy dotyczące egzaminu narzeczonych, zapowiedzi przedmałżeńskich oraz innych odpowiednich środków do przeprowadzenia badań przed zawarciem małżeństwa, aby proboszcz pilnie ich przestrzegając, mógł przystąpić do asystowania przy małżeństwie”. Kan. 1068 K PK: „Jeśli w niebezpieczeństwie śmierci nie można zdobyć innych dowodów, wystarcza - jeśli nie ma przeciwnych podejrzeń - oświadczenie nupturientów, w razie potrzeby zaprzysiężone, że zostali ochrzczeni i nie są związani żadną przeszkodą". Kan. 1069 КРК: „Wszyscy wierni mają obowiązek znane im przeszkody małżeńskie wyjawić przed zawarciem małżeństwa proboszczowi lub ordynariuszowi miejsca”. Kan. 1070 KРК: „Jeśli egzaminu przedślubnego nie przeprowadził proboszcz, do którego należy asystowanie przy zawieraniu małżeństwa, lecz inny, ma on obowiązek jak najszybciej powiadomić tego proboszcza o wyniku badań autentycznym dokumentem". 
sprowadzać się wyłącznie do zapoznania się z treścią ewentualnego zaświadczenia lekarskiego czy opinii psychologicznej. Nie każda wszak osoba, która ma udokumentowaną niepełnosprawność umysłową, jest tym samym niezdolna do zawarcia małżeństwa, podobnie jak i nie o każdej osobie, u której formalnie nie orzeczono niepełnosprawności umysłowej, można z góry powiedzieć, że jest zdolna do jego zawarcia'25.

Nawet jeśli w przypadku jakiejś osoby niepełnosprawnej umysłowo zachodzą uzasadnione wątpliwości, czy będzie mogła funkcjonować w małżeństwie i podejmować istotne obowiązki małżeńskie, duszpasterz nie powinien zabraniać jej zawierania małżeństwa, o ile nie zdobędzie pewności moralnej, że taka osoba zdolności konsensualnej na pewno nie posiada. O potrzebie stosowania właśnie takiej zasady interpretacyjnej wyraźnie stanowi kan. 118 KPK, który nakazuje ścisłą interpretację ustawy wówczas, gdy w grę wchodzi ograniczanie swobody wykonywania uprawnieńn ${ }^{26}$.

W wątpliwości co do występowania zdolności konsensualnej należy działać na korzyść małżeństwa (favor matrimonii). W przeciwnym przypadku dochodziłoby do niedozwolonego ograniczenia prawa naturalnego na skutek braku jedynie wątpliwego. Jeśli proboszcz, pomimo wnikliwej analizy, nie będzie w stanie sam dokonać właściwej oceny sytuacji, zawsze może zwrócić się o pomoc do swojego ordynariusza. W jakim stopniu jednak proboszczowie czują się dziś kompetentni i odpowiednio przygotowani do rozeznawania przesłanek zdolności konsensualnej - to temat na oddzielną publikację.

25 Tak też J. Gręźlikowski, Osoby niepetnosprawne a zawarcie małżeństwa, https://www.przewodnik-katolicki.pl/Archiwum/2016/Przewodnik-Katolicki-2-2016/Diecezja-Wloclawska/Osoby-niepelnosprawne-a-zawarcie-malzenstwa

26 Por. P. Bianchi, Can. 1958, w: Codice di Diritto Canonico, Commentato, Milano 2001, s. 856; W. Góralski, Prawo do zawarcia małżeństwa. Perspektywa kanonisty, „Zeszyty Naukowe KUL” 59 (2015) nr 4, s. 24. 
StRESZCZENIE

\section{Od amencji do borderline. Dopuszczenie do małżeństwa osób z zaburzeniem natury psychicznej?}

Artykuł podejmuje problem możliwości dopuszczenia do małżeństwa kanonicznego osób z zaburzeniami psychicznymi. Z jednej strony nie można bowiem obiektywizować a priori na sposób ogólnego zakazu różnych chorób i zaburzeń psychicznych, jak przy przeszkodach małżeńskich, i zabraniać nupturientom dotkniętym tymi przypadłościami wstępowania w związek małżeński, z drugiej strony nie można wykluczyć, że pewne dysfunkcje natury psychicznej - zauważalne primo facie - mogą w sposób niejako uprzedzający wskazywać, iż dana osoba nie posiada pełnego i harmonicznego zarządzania swoimi władzami zmysłowymi, pożądawczymi, umysłowymi i wolitywnymi, które są konieczne, by akt zawarcia przez nią małżeństwa był aktem ludzkim. Przeprowadzona analiza doktryny kanonistycznej ostatniego stulecia doprowadziła do wniosku, że każdy przypadek należy badać indywidualnie w oparciu o kryteria zawarte w normie kan. 1095 KPK, przy czym osąd, czy nupturienta z zaburzeniami psychicznymi należy dopuścić do małżeństwa, winien być pozostawiony duszpasterzowi, który nie powinien zabraniać zawierania małżeństwa, jeśli nie zdobędzie pewności moralnej, że taka osoba zdolności konsensualnej na pewno nie posiada.

Słowa kluczowe: amentia, borderline, prawo do małżeństwa, konsens małżeński, nieważność małżeństwa 
SUMMARY

\section{From amentia to borderline. Admission to marriage for persons with mental disorders?}

This paper addresses the problem of admitting persons with mental disorders to canonical marriage. On one hand, various conditions and mental disorders cannot be objectivised a priori in the form of a general ban, as is the case with marital obstacles, prohibiting the future bride or groom affected by such conditions from entering into marriage. On the other hand, it cannot be ruled out that some dysfunction of a mental nature - observable prima facie - can somehow prejudicially indicate that a given person does not fully and harmonically manage his or her sensory, desire, mental and volitional capacities that are necessary for an act of entering into marriage by such persons to be considered a human act. The conducted analysis of the canonistic doctrine of the last century has led to the conclusion that each case must be examined individually, based on the criteria provided for in the norm of Canon 1095, while the judgement of whether the specific marriage candidate with mental disorders should be admitted to marriage should be left to the priest, who should not forbid him or her from entering into marriage without being morally certain that a given person absolutely does not have the consensual capacity.

Keywords: amentia, borderline, right to marry, marital consensus, nullity of marriage

Lucjan Świto, Od amencji do borderline. Dopuszczenie do matżeństwa osób z zaburzeniem natury psychicznej?, w: Warunki dopuszczalności do sakramentów, ze szczególnym uwzględnieniem sakramentu matżeństwa, red. Piotr Kroczek, Kraków 2017, s. 101-117 (Annales Canonici Monographiae, 7).

DOI: http://dx.doi.org/10.15633/9788374388153.06 
